Ohio," I879, in which paper I particularly urged the influence of atropia in sustaining the heart's action; further, in American edition "Holmes' Surgery," and several times in journals.

Now, I do not wish to trouble you, and care little about the personal honor of priority in this matter, but think that when a procedure is published as a good thing, being so discovered abroad. those who have worked at it for many years before in this country deserve mention.

In speaking of priority of this process, I do not claim originality', but only that I have been a persistent and repeated advocate of it. I believe it to be one of the most important and most valuable modifications of the anæsthetic process. Nussbaum first used it. When in Münich, in I 887 , I took the trouble to call upon him in reference to it, but found that he never carried it beyond his first essay.

The method was placed upon a scientific basis by Bernard ("Lecons sur l'Asphyxie et l'Ancesthetic'), and the results as to death of dogs there given is quite as striking as that in the article you have published.

I am very respectfully and truly yours,

Dayton, O., October I9, I889.

J. C. REEVE, M.D.,

\section{Tenth International Medical Congress.}

To the Editor:-I have received the following letter from Professor Virchow, the President-elect of the next Medical Congress.

Very truly yours,

John B. Hamirton.

Treasury Department, U. S. Marine-Hospital Bureau, Washington, D. C., October 30, I889.

BERLIN, October I, I889.

Dear Sir:-The Organizing Committee of the Tenth International Medical Congress is now constituted. I myself am elected President, and Dr. Lassar (Karlstrasse I9, N.W.) Secretary-General. We will be very happy to receive the Transactions of the Ninth International Congress, and we hope to see you and many of your countrymen at the new session.

I am, sir, very sincerely your obedient servant, PROFESSOR RUD. VIRCHOW.

\section{Holland Claims the Microscope.}

To the Editor:-Allow me to call your attention to an error in THE JOURNAL of September I $4^{\text {th }}$, which mistake I have recently seen in one or more other journals. On page 385 of THE JOURNAL, under the caption of "The Tercentennial of the Microscope," you ascribe the invention of that highly useful instrument to a Zacharias Janssen, of Magdeburg, the capital of a Prussian province, Saxony. Zacharias Janssen, to whom belongs the credit of constructing the first compound microscope (the simple microscope was known previous to that time), was not a German but a Hollander, born and reared in Middelburg, the capital of the province of Zeeland, one of the eleven provinces of the United Netherlands.

Germany and the Germans seem particularly anxious to monopolize the credit of most of the useful inventions-now they lay claim to the invention of the microscope. "Honor to whom honor is due." J. VANDERLAaN, M.D.

Muskegon, Mich., September I4, I8S9.

\section{NECROLOGY.}

\section{D1. Isaac E. Taylor.}

This distinguished physician, so well known to the medical profession and so highly honored, died at his residence in West Thirty-fifth street, New York City, on the 3 oth ult., at the age of 77 years. He was from the time of its organization until his death the first and only President of Bellevue Hospital Medical College, and has always been esteemed as one of the foremost promoters of medical education.

About ten days previous to his death he was attacked with acute pericarditis and was confined to his bed. Up to the moment of death he had not been considered seriously ill. While lying in bed and reading from a book his daughter noticed that he suddenly threw his hand over his head, sank into his pillow and in three-quarters of an hour he was dead. Mrs. Taylor died in I867. Four children-Mrs. Pierre Lorillard, Col. Stewart Taylor, Mrs. Hilliard M. Judge, and an unmarried daughter, are his immediate surviving relatives. His was a well rounded life, full of years, of unusual achievement and of signal honors. To the family bereaved and to the Faculty of the College, the profound sympathy of the profession will be most freely accorded.

\section{Dr. I. F. Warner.}

DR. LEVI FARR WARNER, of Boston, for many years an influential member of the American Medical Association, and in I 874 one of its VicePresidents, was born Oct. 25, 1822, at Norwich, Chenango Co., N. Y. He died Oct. I2, I889, at Boston, two weeks before the completion of his 67 th year. Educated preliminarily at the Academy at Mexico, N. Y., he studied for his profession during $1842-3$ at Geneva Medical College, and subsequently graduated in $\mathrm{r} 862$ at Lind University, Chicago. He commenced practice at Vienna, at Oneida Co., N.Y., and removed thence to St. Louis, where during the war he was Ass't Medical Examiner for the First District of Missouri. He then came to Boston, and was admitted a member of the Massachusetts Medical Society. He was one of the founders of the Gynæcological Society of Boston, and soon became recognized as of especial skill in the diag- 